\title{
New Jersey - A Leader in Fighting Pollution
}

\section{Federal-state partnership to improve air quality benefits from clean energy projects}

How much do state-funded energy programs reduce air emissions? The Department of Energy's (DOE) Office of Energy Efficiency and Renewable Energy (EERE) worked with the state of New Jersey to estimate reductions in nitrogen oxides (NOx) resulting from the state's publicly funded Clean Energy Program (CEP). New Jersey is one of the first to apply a streamlined method to estimate the emissions effect of its renewable energy (RE) and energy efficiency (EE) programs. This fact sheet outlines the elements of this groundbreaking pilot project.

\section{Approach}

Working with New Jersey officials, the DOE pilot project team refined a method for calculating summer NOx emissions reductions from RE and EE programs under the New Jersey CEP. Emissions of NOx were targeted due to their contribution to summertime ozone pollution. Calculations estimated energy savings and renewable

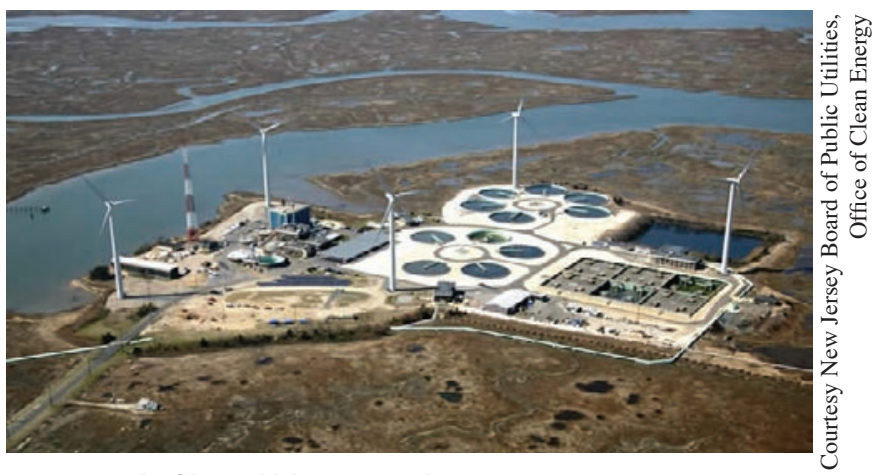

The Atlantic City Utilities Authority Wastewater Treatment Facility features the 7.5 MW Jersey-Atlantic Wind Farm and a $500 \mathrm{~kW}$ solar project. When dedicated in December 2005, the wind farm was the first in New Jersey, and the solar project was the second largest in the state. generation, displaced electric-sector emissions, and the ozone season share of those emissions. The project team analyzed energy efficiency projects in new construction and retrofits of commercial, industrial, and residential buildings and schools; ENERGY STAR ${ }^{\mathrm{TM}}$ air conditioning and lighting; high efficiency air conditioning and ground source heat pumps; and solar photovoltaic projects.

Collaboration was a key component of this effort. Project team members included DOE-EERE, the National Renewable Energy Laboratory (NREL), the Environmental Protection Agency (EPA), the New Jersey CEP, the New Jersey Department of Environmental Protection (NJDEP), and outside consultants. A strong working relationship and leadership from state agencies is crucial for moving similar projects forward.

\section{Methods of Quantifying Emissions Reductions from Implementing RE and EE technologies}

To quantify energy effects and NOx reductions, the team refined and expanded methodologies that were initially developed by the CEP. This project methodology:

1. Estimated electricity savings from the energy efficiency measures and electricity generation from renewable sources (both annual and summer ozone season).

2. Estimated the annual and summer ozone season NOx emission rates from power plants serving New Jersey.

3. Calculated the resulting displaced NOx emissions.

The team calculated that the state had reduced electricity generation in 2005 by 322,998 megawatt-hours (MWh). A number of different assumptions could be used to extrapolate these results to the 2005 through 2012 summer ozone seasons, so a base case and four alternative scenarios were developed. The base case is presented here - the other results, energy savings estimation methods, and measure-specific results can be found in Final Report on the Clean Energy/Air Quality Integration Initiative Pilot Project of the U.S. Department of Energy's Mid-Atlantic Regional Office at www.eere.energy.gov/wip/pdfs/40477.pdf.

Although this analysis focused on emissions reductions, other potential benefits of $\mathrm{EE}$ and RE technologies include economic development and job creation, price stability through fuel diversification, and enhanced energy security. 


\section{Results}

A primary goal for this project was quantifying displaced emissions in a streamlined manner that could be readily applied by other state and local agencies. Before this project, other states (such as Texas) had estimated displaced emissions from electric-sector EE and RE projects using streamlined methods. The New Jersey project developed a different streamlined method to estimate reduced emissions during the summer ozone season, using a generation-weighted average of the emissions from fossil fuel units. This method could be compared to other streamlined methods or to the more complex approach of modeling the dispatch of individual fossil units, as was used in Illinois (see www.nrel.gov/docs/ fy08osti/42164.pdf and www.nrel.gov/docs/fy080sti/42165.pdf).
Ozone Season NOx Reductions - Base Case Results

\begin{tabular}{|c|c|c|c|}
\hline Year & $\begin{array}{c}\text { Summer Electricity } \\
\text { Savings (MWh) }\end{array}$ & $\begin{array}{c}\text { N0x Displaced } \\
\text { Emissions Rate } \\
\text { (Ib/MWh) }\end{array}$ & $\begin{array}{c}\text { N0x Emissions } \\
\text { (tons) Displaced }\end{array}$ \\
\hline 2005 & 322,999 & 1.50 & 242 \\
\hline 2006 & 459,635 & 1.50 & 345 \\
\hline 2007 & 613,387 & 1.24 & 380 \\
\hline 2008 & 789,413 & 0.97 & 383 \\
\hline 2009 & 993,723 & 0.92 & 458 \\
\hline 2010 & $1,233,412$ & 0.88 & 540 \\
\hline 2011 & $1,516,942$ & 0.83 & 631 \\
\hline 2012 & $1,854,483$ & 0.79 & 733 \\
\hline
\end{tabular}

The project team calculated a base case in which New Jersey could avoid 733 tons of ozone season NOx emissions by 2012 by implementing selected CEP programs. The table above summarizes potential NOx emission reductions from 2005 through 2012 in pounds per megawatt-hour (lb/MWh). The team also recommended amendments to New Jersey's NOx emissions trading regulations. To facilitate accounting for these emission reductions in the state implementation plan, New Jersey proposed amendments to its NOx emissions trading regulations clarifying that state-funded projects can qualify for NOx allowances and would be required to retire such allowances to achieve real NOx emissions reduction. In addition, the proposed regulation would clarify that the state could aggregate small projects in the allowance allocation process, providing improved incentives for small efficiency and photovoltaic projects that otherwise would not qualify for NOx allowances.

\section{Next Steps}

- While New Jersey is working to apply results from this analysis, other states have the opportunity to undertake similar efforts to address emissions. In fact, Maryland and several other eastern states already have benefited from the new methodologies. States are looking to estimate avoided NOx emissions from RE and EE as they develop control measures for both fine particulate matter and ozone. In addition, several jurisdictions are considering the applicability of this methodology to estimate greenhouse gas emission reductions resulting from RE and EE programs.

- In June 2007, EPA announced a proposed rule to tighten the existing air quality standard for ozone, which is expected to bring hundreds of additional counties into nonattainment status. This action will likely heighten state and local government interest in using RE and EE measures to meet the future ozone standard and will increase demand for these technologies in the marketplace.

\section{Lessons Learned}

The New Jersey pilot project established a foundation from which other states can build to use clean energy programs to comply with existing federal air quality regulations, reduce future greenhouse gas emissions, and reduce energy costs. Findings include:

- Insight on developing future policies to fully credit emission reductions from energy efficiency and renewable energy projects under current and future emissions trading programs (e.g., greenhouse gas emissions trading programs).

- Importance of aggregation of small projects in emissions trading regulations, which is necessary to monetize the value of such projects under air quality regulations.

\author{
Additional Information \\ Program Assistance \\ James M. Ferguson \\ National Energy Technology Laboratory (NETL) \\ james.ferguson@netl.doe.gov \\ 412-386-6043 \\ Technical Assistance \\ Laura Vimmerstedt \\ National Renewable Energy Laboratory (NREL) \\ laura_vimmerstedt@nrel.gov \\ 303-384-7346 \\ New Jersey State Information \\ Tom McNevin \\ New Jersey Department of Environmental \\ Protection (NJDEP) \\ tmcnevin@dep.state.nj.us \\ 609-984-9766
}

DOE/G0-102007-2399, December 2007
A Strong Energy Portfolio for a Strong America

Energy efficiency and clean, renewable energy will mean a stronger economy, a cleaner

environment, and greater energy independence for America. Working with a wide array of state, community, industry, and university partners, the U.S. Department of Energy's Office of Energy Efficiency and Renewable Energy invests in a diverse portfolio of energy technologies. Energy by the National Renewable Energy Laboratory, a DOE national laboratory. Printed with a renewable-source ink on paper containing at least $50 \%$ wastepaper, including $20 \%$ postconsumer waste.
For more information contact: EERE Information Center

1-877-EERE-INF

(1-877-337-3463)

www.eere.energy.gov 